question of 1938 is to be found in the report by J. da Silva Horta and his colleagues" of Lisbon. They have traced as many as possible of 2,377 patients in Portugal in whom Thorotrast was used between 1930 and 1952. Adequate information was obtainable about 1,107, of whom 699 had died and 408 were still living at the end of 1963 . Death had been due in 22 patients to haemangioendothelioma of the liver, a tumour almost unknown except from this cause. Fibrosis of the liver occurred in 42 , and as a cause of death in 17. Leukacmia or aplastic anaemia developed in 16 . A granuloma at the site of injection occurred in 81 patients, causing death in 8 and being complicated by malignancy in 3. Malignant tumours at various other sites occurred in 22. The latent periods between administration of Thorotrast and the development of these conditions were about 5 years for granulomas, 15 for liver fibrosis, and 20 for liver tumours and leukaemias, although a few occurred much earlicr. The authors admit that without comparison with a matched population, and without other information not available in Portugal, some of these findings are not conclusive, but the frequency of blood diseases is clearly excessive and the relation between cause and effect in the unique liver tumours is indisputable. They conclude that Thorotrast should never be administered to patients with a life expectation of more than two years.

After this thorough investigation it hardly seems necessary to undertake further follow-up studies in other countriesindeed in some ways it might even be inadvisable. But it is well to have been made aware of the possible connexion between certain malignant and blood diseases and a diagnostic procedure conducted some twenty years earlier.

\section{Quekett and Microscopy}

This year marks the centenary of the Quekett Microscopical Club, founded in honour of John T. Quekett, one of the foremost microscopists of the first half of the last century. To celebrate the event a two-day meeting and exhibition of microscopy, open to visitors, will be held at the Central Hall, Westminster, on 8-9 October. Although he was medically qualified, his name is better known in scientific than in purely medical circles. After studying at King's College and the London Hospital he qualified in 1840 and then spent almost the whole of his working life at the Royal College of Surgeons.

Youngest son of the headmaster of Langport Grammar School in Somerset, Quekett early showed interest in natural history and the microscope. Even at the age of 16 he had made his own microscope and was giving a course of lectures on microscopy. He was sent to London to become apprenticed to his elder brother, who in addition to being a physician with a private practice was also lecturer in botany to the London Hospital. Soon after graduation he was awarded a three-year studentship in the Department of Anatomy at the Royal College of Surgeons. His ability in making and arranging microscopical preparations was soon recognized, and at the end of his studentship he was appointed assistant to the Conservator of the Museum, Professor Richard Owen. When Owen left to take up an appointment at the British Museum in 1856 Quekett was given the title of Professor and chosen to succeed him. He held this post till 1861, when after a period of declining health he died on 20 August at the early age of 46. A Fellow of the Royal Society and of the Linnean Society, Quekett wrote extensively and published Lectures on Histology and Practical Treatise on the Use of the Microscope. His personal diaries are of great interest and are kept in the library of the Royal College of Surgeons, but little of them has been published. It is hoped to publish a selection of them to mark the centenary of the club.

At a time when histology was in its infancy the Council of the Royal College of Surgeons is to be commended for its foresight in establishing a professorship in the subject in 1841 . Microscopy grew rapidly in the following years, and, in an era when research grants were unknown, advances were made by amateurs who studied the subject as a hobby. There were many amateur societies at this time, and it was largely due to the energy of $M$. C. Cooke, an eminent mycologist and president of the Society of Amateur Botanists, that the Quekett Club was founded in 1865 . The enthusiasm can be gauged by the fact that in its early years the club had nearly 700 members. Since that time it has met regularly and the membership now stands at about 350. Many famous scientists have occupied the presidential chair, including Edwin Lankester (the first president and father of E. Ray Lankester), M. C. Cooke, E. M. Nelson, T. H. Huxley, E. A. Minchin, and Hamilton Hartridge to mention but a few. The president for the centenary year is Professor George J. Cunningham, the Conservator of the Pathological Collection at the Royal College of Surgeons of England.

In Quekett's day rapid progress was being made in microscopy, and achromatic objectives were in use. Quekett dedicated the Practical Treatise to Joseph J. Lister, the father of Lord Lister, for his contribution to the development of objectives. Lister made the discovery that the use of aplanatic foci of a pair of doublets resulted in the production of objectives of greatly improved quality. The modern light microscope really came into general use when resolution was much improved by the introduction by Abbe of the condenser in 1878 and the apochromatic system in 1886. Condensers had been known for more than a hundred years but were only occasionally used by a few individuals. Amici discovered the immersion system for high-power work in 1840 , but it was not until about 30 years later that it became widely used in the era in which many pathogenic bacteria were discovered. In the succeeding years experiments were made with different lighting systems such as ultra-violet and dark-ground illumination. In this field the most important advance was in 1934 , when Zernicke invented phase-contrast microscopy. By this technique, which became more fully applied to research after the second world war, preparations of living tissue can be observed, and the way was paved for a new chapter in dynamic pathology. The electron-microscope was developed at about the same time, though technical difficulties and cost delayed its extensive use until the last 15 years. Of later origin was the interference microscope, by means of which quantitative estimations can be made and which also provides images free from halo.

At present these new forms of microscopy are responsible for many advances in knowledge, and the technique of tagging substances with fluorescent dyes has proved revolutionary in pathology, immunology, and microbiology. Autoradiography has enabled radioactive compounds to be located in microtome-sections, thus indicating the exact site of certain cellular reactions. The use of histochemical techniques in electron microscopy holds out great hopes for the future in the study of tissue metabolism in both health and disease. 